\title{
Immaterial Fordism: the paradox of game industry labour
}

\section{Leif Schumacher}

\author{
Leif Schumacher is a Ph.D. Candidate in Communication \\ researching the political economy of the interactive games industry \\ at Carleton University, Ottawa, Canada, .
}

\begin{abstract}
In different ways, Marxist autonomist, regulation school, and neoliberal theories all claim that work in the new economy is increasingly characterised by high levels of creativity, cooperation, and innovation, albeit accompanied by uncertainty and a relentless pace of work, introducing a new form of labour that differs fundamentally from past forms. This paper does not disagree with the proposition that capital is currently in the process of intensifying its search for more efficient value extraction. However, through a case study of lawsuits launched against the video game company Electronic Arts regarding its labour practices, it argues that the change in the nature of knowledge work and immaterial labour has been overstated by the adherents of these three schools and that what we are witnessing is not so much a replacement of traditional Fordist practices by post-Fordist ones as a new fusion of the two forms.
\end{abstract}

The starting point for this paper is a single blog entry in early November 2004 which stirred up enormous controversy and attention. Identifying herself as a 'disgruntled spouse' (or EA_spouse, as her signature read) this blogger described the experience of her partner who worked as a programmer for Electronic Arts (EA), the world's largest independent video game producer. His work involved 90-hour 'crunch' workweeks for which he received no compensation either in terms of overtime pay or extra vacation. These were labour conditions that had more in common with sweatshops than what would be expected in Silicon Valley - the leading beacon of the so-called knowledge-based economy. Rresponses to the blog posting were immediate, and within a day the trade press had picked up the story. Earlier the same year, the International Game Developers Association (IGDA) had released a comprehensive study that highlighted many of the same issues that EA_spouse detailed, but it had received scant attention. Now, the study was quickly revisited by the trade press, and in addition it came to light that EA had earlier the same year been hit by a class action lawsuit that claimed the company was breaking California labour law with their practice of requiring unpaid overtime.

This paper focuses on these class action lawsuits and subsequent settlements and what they reveal about the status of so-called creative workers in the new economy. It focuses on the computer and video games industry because it, and the commodities it produces, seem to epitomise the cultural content, marketing practices, production processes, consumption patterns, and labour conditions that are symptomatic of what 
David Harvey (1989) has described as a sea-change in political, economic, and cultural practices related to a shift in the organisation of capitalism. The industry is based on a knowledge-based symbolic output geared towards entertainment, produced almost exclusively using modern information and communication technology, within an environment relying on creativity and innovation. If we understand how the video game industry operates we should be able to illuminate many aspects of the functions and consequences of the reorganisation of capitalism.

One aspect of this industry, labour conditions and organisation, is examined in this paper, drawing on a secondary analysis of a series of lawsuits that claim improper classification of video game production personnel as creative workers. The argument made by these lawsuits - that these workers are not engaged in autonomous creative labour - problematises Marxist autonomist, regulation school, and neoliberal theories that claim that work in the new economy is increasingly characterised by high levels of creativity, cooperation, and innovation, albeit accompanied by uncertainty and a relentless pace of work. The evidence from these cases suggests that, even though the labour involved may be immaterial, it still appears to be carried out under conditions that are more characteristic of some of the 'old' production paradigms.

\section{Converging theories}

Discussing what is variously known as the 'creative', 'information' or 'knowledge' economy, analysts and commentators as diverse as Robert Reich (1991; 2002), Frances Cairncross (1997), Diane Coyle (1998), Manuel Castells (2000; 2001), and Richard Florida $(2002 ; 2005)$ have painted a picture of a new economic landscape, enabled by new information and communication technologies, where creativity, knowledge and information have become the key factors that determine increased productivity and competitiveness, and general economic growth. Because these factors largely reside inside workers' heads, the argument goes that we are witnessing a transformation where labour is increasingly valued for workers' mental inputs rather than their physical skills.

Such views can be seen as representing a convergence between three different theoretical traditions: neo-liberal theories, those of the French regulation school and those of Marxist autonomists. To the French regulation school, with its concepts of 'mode of regulation' (Aglietta, 1979) or 'regime of accumulation' (Lipietz, 1987) we owe the idea that we are currently witnessing the transition from a Fordist to a postFordist regime, where the development and use of new information technologies play a central role in the shift towards a regime of flexible labour and production, intensified consumption, and constant innovation (Jessop, 2002). In this view, the consequence for labour is that flexibility translates into uncertainty, contracts become more precarious and workers face constant pressure to update their skills. Marxist autonomists have critiqued this approach for taking insufficient account of the formative potential of class struggle (Gambino, 1996; Dyer-Witheford, 2004). Agreeing that the mass worker has been largely replaced by the socialised worker as a result of major change in the organisation of capitalism (the emergence of 'Empire') this approach emphasises the introduction of new network technologies and new accumulation strategies as an effort 
to disperse the collective power of the mass worker (Hardt and Negri, 2000). In this model the homogeneous mass worker is replaced by the heterogeneous 'multitude' engaged in 'immaterial labour', which is viewed as inherently cooperative, and contains a strong potential for liberation through the use of the very tools and tendencies introduced by Empire (Hardt and Negri, 2004). This view has been criticised for putting too much emphasis on the dichotomy of 'Empire' versus 'multitude' (Thoburn, 2001) and for failing to recognise divisions within the 'multitude' based on, for instance, gender and ethnic differences (Dyer-Witheford, 2001). Despite these differences, it can be argued that the overall context is one of convergence between these different theoretical approaches. From Harvey to Florida, from Negri to Jessop there is a common perception that capitalism has entered or is in the process of entering a new phase of expansion characterised by intensified creative/information/knowledge work, flexible work arrangements, and a postmodern culture of consumption.

Video game production is often viewed as the pinnacle of creative work, involving artistry in everything from the fantasy of the storyline and the ingenuity of the game mechanics to the spectacular graphics and sound that make up crucial dimensions of the video game experience. This type of labour should supposedly illustrate the work arrangements envisioned, for example, by Florida (2002) and Reich (2002), who describe a creative knowledge-based economy with labour markets full of new opportunities for those with the requisite skills. Dyer-Witheford (2002) speaks of this as the 'work as play ethos', where the prospect of a 'hip' creative workplace is welcomed despite the prospects of long hours and job insecurity.

This paper argues that the reality is much more contradictory than this and that there is clear evidence of working conditions within the industry that are standardised and closely monitored, with as many Fordist as post-Fordist characterisitics. The lawsuits studied do not only reveal knowledge work performed according to such Fordist standards; but they also demonstrate that the 'multitude' (or at least those parts of it represented by the workforce in these games companies) has chosen avenues of resistance that do not form part of the tools and tendencies put in place by 'Empire'.

\section{The context - structure of the video game industry}

Video game production has established itself as a strong and growing global industry. With major investment from large multinational corporations such as Sony, Microsoft, and Vivendi, it produced global revenues of approximately US $\$ 28$ billion in $2005^{1}$, and is expected to nearly double that by 2010 (Cole, 2005). According to PriceWaterhouseCoopers the growth of the video game industry is set to outpace all other entertainment sectors by the end of the decade (Fahey, 2005). The map of the industry involved in developing and publishing computer and video games is constantly changing through takeovers, mergers, bankruptcies, and the emergence of new actors. However, some basic contours can be discerned.

$1 \quad$ All dollar figures mentioned from here on are in US dollars, unless otherwise mentioned. 
At the top of the hierarchy we find the publishers (e.g. Electronic Arts, Activision, UbiSoft and Take-Two Interactive). They stand as gatekeepers between developers and the market, providing the financial muscle needed for distribution and marketing. Many publishers employ their own large in-house development teams (often the result of acquisitions of successful independent developers), but they also rely on contracting work out to independent developers. This helps mitigate the risk of operating in a hit-driven business with an alleged 95 per cent failure rate (International Game Developers Association, 2004). Independent developers range in size from a handful of people operating from a basement to large multinational operations employing hundreds of people. Acquisition is a common strategy in this industry, and as soon as an independent developer produces a successful game the chances are that a larger company will buy it out to capitalise on the prospects of continued sales and development of successful sequels.

The escalating costs associated with game production, as hardware has become increasingly sophisticated, are a growing concern. With the release of the next generation of consoles (Microsoft's Xbox 360, Nintendo's Wii, and Sony's Playstation 3) development costs are expected to reach $\$ 15$ million per game. On top of this must be added the costs associated with marketing and SG\&A (selling, general, and administrative expenses), which could bring total costs as $\$ 25$ million (Gamedaily Staff, 2006). At this price point there is enormous pressure to produce games that stay on budget and sell in large quantities, since over a million copies might have to be sold just to break even. Several strategies are implemented in order to achieve this, and one consequence is that many firms put pressure on their workforce to increase their working hours in order to maximise output, even when they are engaged in so-called creative endeavours (Handman, 2005).

\section{The labour process and the people engaged in it}

About 100,000 people are engaged in game related labour in North America (Bass, 2005). It is uncertain exactly how many of these are directly working with game development since job descriptions range from public relations personnel and game testers to software engineers and product managers. However, it is clear that game development labour forms the foundation of the industry, supplying content and digital code (Kline, Dyer-Witheford and de Peuter, 2003).

Producing a game can take anything from six months to two years, and work is mostly conducted in teams involving up to 100 people. Designers create the vision for the game (what characters are involved, the mechanics of the game, etc.), artists provide the visual and audio content, and programmers build the code that acts as the engine of the game (de Peuter and Dyer-Witheford, 2005). Overseeing the project we find the producer, who is responsible for the overall functioning of the team. He (in the vast majority of cases it is a 'he') must coordinate all development efforts, schedule deadlines, manage budgets, provide the proper tools for his team, and ensure that development stays within the bounds of the overall vision of the game (Irish, 2005). At the lowest rung of the ladder we find the game tester who is involved in the quality assurance process. Testers are generally only paid the minimum wage. 
Through interviews (about 40) conducted by de Peuter and Dyer-Witheford (2005), a quality of life survey (994 respondents) and a workforce diversity survey (filtered sample size of 3,128 respondents) carried out by IGDA $(2004 ; 2005)^{2}$ we have a fairly good idea of the demographics of the industry. The people involved in game development are overwhelmingly young white males, with an average age of 31 years. Most are between their early twenties and mid thirties, with the majority having worked in the industry for less than five years.

The picture that emerges both from the surveys and the interviews is of a workforce that is generally content with the work, enjoying flexibility and autonomy, a variability of creative work tasks, intellectual freedom, high levels of cooperation, and a playful work environment. This despite reports of high turnover rates, a culture of long hours, and complaints from immediate family that they do not get to spend enough time with their significant others.

According to de Peuter and Dyer-Witheford (2005) 'game development is an exemplary site of "immaterial labour". Following Hart and Negri (2000) they use the term immaterial labour to refer to the emotional, creative, networked, socialised work in which the 'multitude' is engaged in our era of high technology. Referring to the work of Maurizio Lazzarato, they point out how he 'emphasises the centrality of "inventive work" to contemporary production, an aspect of the performance of immaterial labour that he contrasts to the "reproductive work" characteristic of the mass production of similar goods in the Fordist era'. Their study found many features supposedly typical of immaterial labour in game development, such as individual creativity, digital and social networking, and a culture of subjective self-fulfillment, but also precariousness and uncertainty.

Rossiter (2003) points out the remarkable similarity that can be found between such arguments coming from the autonomists and the 'neoliberalism' of writers like Richard Florida and Charles Leadbeater who have discussed similar phenomena. Here, for instance is Florida on creativity:

'Creativity has come to be the most highly prized commodity in our economy - and yet it is not a 'commodity.' Creativity comes from people. And while people can be hired and fired, their creative capacity cannot be bought and sold, or turned on and off at will. ... Creativity must be motivated and nurtured in a multitude of ways, by employers, by people themselves and by the communities where they locate.' (Florida, 2002: 5)

This description can be compared with Negri's (2003) notion of the multitude emerging 'when labour starts being regarded as something that can no longer be directly exploited.' Instead it is the social relationships between workers - their cooperation - that is exploited. This notion is further developed in de Peuter and Dyer-Witheford's (2005) description of game labour, as involving the 'capture of human creativity' made possible through work processes focusing on the combination of cooperation and individual creative freedom.

2 The complete results of the Quality of Life survey (including the raw data) can be downloaded at: http://www.igda.org/qol/whitepaper.php The complete results of the diversity survey (including the raw data) can be downloaded at: http://www.igda.org/diversity/ 
Florida (2002:327-328) does not speak of the 'multitude', but he postulates the emergence of a new class of workers valued for their creativity, and who, according to his calculations, make up about a third of the total American workforce. Workers who are involved in the production side of video games are not only included in this class but, because they belong to the US Bureau of Labor Statistics 'computer and mathematical occupations' category, would even form part of what he calls the 'super-creative core'. Florida's argument in many ways reflects the features identified by Leadbeater (1997) as key to the economic success of Silicon Valley in the mid-90s. Leadbeater saw a culture dominated by creativity, individualism, diversity, meritocracy, risk, and high performance. In his view this culture was the driving force behind the re-emergence of the Californian economy from its troubles in the late 80 s and early 90 s resulting from the loss of manufacturing jobs. Here we also find similarities to the regulation school, which speaks of innovation and knowledge work as characteristic of the demands made of labour in the emerging regime of accumulation based on post-Fordist production processes.

Combining these converging views, albeit simplistically, leads to the presumption that workers in the gaming industry are likely to be more highly skilled and creative than their Fordist counterparts but that this may come at the price of uncertainty and a volatile work/life balance. It would thus be expected that any lawsuit launched by workers against firms in this field would focus on these issues.

\section{The case study firm}

The lawsuits examined here were all targeted at Electronic Arts (EA), a behemoth of the gaming industry, which stands out as the largest independent publisher/producer of video games. According to EA's 2005 annual report the company had a net revenue of $\$ 3.1$ billion, and published 31 titles with worldwide sales of over a million copies ${ }^{3}$. EA has established development studios in North America, Europe and Asia. Two of these studios, employing a total of 6,800 people, are located in California, in Los Angeles and Redwood City in Silicon Valley. According to Develop Magazine's annual ranking based on sales in the UK market (the world's third largest video game market) these are among the most successful production studios in the world (Graft, 2006a).

\section{The lawsuits}

On July 29, 2004, Schubert \& Reed LLP and Shapiro, Haber \& Urmy LLP filed a class action lawsuit before the San Mateo County court on behalf of Jamie Kirschenbaum, who at the time worked as a so-called 'image production employee' at EA's Redwood studio (InterNet Bankruptcy Library, 2005a).

The class action lawsuit alleged that EA unlawfully classified image production employees as workers exempt from overtime pay under California labour law. The term 'image production employees' covers several different job titles including modellers, texture artists, lighters, background effects artists, and environmental artists (Feldman, 2005). These are the people who produce the visual and audio content of the games 
which form the industry's core products, performing work that most observers would expect to be described as 'creative' or even 'artistic'.

The California labour code sets out minimum standards for workers' regular and overtime compensation, working hours, health and safety, protection against discrimination, appeals processes, etc ${ }^{4}$. In 1999, the California Assembly, through Bill 60, reinstated California's original eight-hour overtime law that had been repealed in 1998 (Jordan and Steen, 2000; Bar-Cohen and Carrillo, 2002). This applied to numerous professionals, and mandated extra pay for any work exceeding eight hours a day or 40 hours a week (Smith, 2004). Bill 60 met with stiff resistance from Silicon Valley executives. Intense lobbying led a year later to the introduction of Senate Bill 88 which amended the overtime legislation, making certain types of workers (computer and health-care professionals) exempt from receiving overtime pay (Jordan and Steen, 2000; Marsh, 2000). This exemption applies to workers that are 'primarily engaged in work that is intellectual or creative and requires the exercise of discretion and independent judgment' (State of California, 2003). In addition, the workers must earn $\$ 41$ per hour (equivalent to an annual salary of $\$ 85,280$ ) in order for the exemption to apply.

EA's image production employees were not paid overtime, and the Kirschenbaum v. EA complaint filed before the court provided detailed information about the type of work performed and the hours required. The main argument was that image production employees were not engaged in creative work that required independent judgement and therefore should be eligible for overtime pay. The complaint alleged that the employees covered by the lawsuit frequently worked more than eight hours a day and 40 hours a week, including weekends and national holidays, without overtime compensation. Regardless of their salary, it was argued, they should not be exempt from overtime pay, because they worked under strict supervision and their task was simply to mount images that were the result of the creative labour of others. The complaint described a hierarchical work process where independent creative decision-making took place among producers, designers, concept artists, and art directors. The image production employees were to be found further down the ladder, being required to follow the orders handed to them strictly, to the point where art directors and producers would monitor their work over their shoulders. The work duties described, it was argued, would not allow these workers to be exempt under California overtime laws. The complaint went on to claim that EA had a 'common policy and practice of classifying all Image Production Employees as exempt from the California overtime laws - while at the same time [assigning them] duties inconsistent with exempt status.' (Schubert, Reed, Kolbe, Urmy, and Heyman, 2004)

The Kirschenbaum v. EA lawsuit was eventually successful. In October 2005, the company released a notice to the press announcing that the suit had been settled. EA was to pay $\$ 15.6$ million to cover all claims by the class members (Muller, 2005) in a settlement covering 618 current and former employees (Heyman, n.d.a). Another

4 The complete up-to-date California Labor Code can be found at http://www.leginfo.ca.gov/cgibin/calawquery? codesection=lab\&codebody=\&hits=20. Details of exemptions can be found at http://www.dir. ca.gov/dlse/faq_overtimeexemptions.htm. 
similar lawsuit (Leander Hasty v. Electronic Arts) involving software engineers (programmers) was settled on April 25, 2006. This settlement was worth \$14.9 million, and covered 600 class members (Brightman, 2006; Heyman, n.d.b; Muller, 2006).

Improper exemption practices are not only limited to a single company, state, or industry. Sony Computer Entertainment America, Activision, Electronic Arts in Florida, IBM, and Siebel Systems (a world-leading producer of Contact Relations Management software) have all been hit with similar lawsuits (Associated Press, 2006; Graves, 2004; InterNet Bankruptcy Library, 2005b; Schubert, Reed, Kolbe, Urmy, and Heyman, 2005; Smith, Urmy, and Heyman, 2005; Urmy and Heyman, 2006). The case against EA in Florida was settled in October 2005 for a total of $\$ 785,000$ covering 119 class members (Heyman, n.d.).

\section{Conclusions}

What do these results tell us about 'immaterial labour' in the new economy?

In a memo sent to North American employees in late 2004, EA's Vice President of Human Resources, Rusty Rueff, responded to the improper classification allegations by stating that the company considers many of its employees to be creative and skilled professionals that relish flexibility in an environment built on a spirit of entrepreneurialism and innovation (Frauenheim, 2004b). This kind of rhetoric is in line with Richard Florida's argument that they form part of a creative class. Florida $(2002 ; 2005)$ postulates an inherent creative knowledge-based individuality that is shared by the entire creative class, and that is attractive to prospective employers. He argues that these employees enjoy a privileged class position in their capacity as creative workers:

'Those in the Working Class and the Service Class are primarily paid to execute according to plan, while those in the Creative Class are primarily paid to create and have considerably more autonomy and flexibility than the other two classes to do so.' (Florida, 2002:8)

As we have seen, the regulation school and the autonomists share similar sentiments regarding the position of workers in the new post-Fordist era of capitalist organisation. Jessop (2002:99) speaks of a post-Fordist virtuous circle of growth that would among other things involve 'rising incomes for skilled manual and intellectual workers (often jointly reclassified as 'knowledge workers')'. Specifically addressing game production labour and drawing on Hardt and Negri (2000), Dyer-Witheford (2002) claims that 'such 'immaterial labour' is completely unamenable to Taylorist/Fordist management techniques.'

However, the reality examined in this paper demonstrates a class of workers that are engaged in immaterial labour, but basically employed as production workers who are not expected to exercise independent judgement or contribute creatively to the value-adding process. Although they are employed for the sake of their mental capacity and knowledge rather than their physical skill, the method for extracting the value of this knowledge mirrors the closely monitored standardised work processes of the assembly line. It could be argued that what we are witnessing here is a form of immaterial Fordist labour, a form which does not fit into any of these three characterisations of the new era. In response, 
both the autonomists and the regulation school would probably argue that what is theorised as a new phase, at the moment constitutes tendencies towards reorganisation, rather than a complete break with the past. As 'Empire' attempts to establish itself, and a new regime of accumulation is becoming visible, old assembly line mass production methods still exist hand in hand with flexible production and immaterial labour (de Peuter and Dyer-Witheford, 2005; Jessop, 2002). This study, however, suggests not so much a scenario in which assembly line Fordist production exists alongside knowledge work based on creativity and symbolic manipulation, but rather a fusion of Fordist and knowledge work practices. Furthermore, this new form does not seem to constitute an isolated exception but appears to be a dominant form of work amongst a large segment of workers in the game production industry.

De Peuter and Dyer-Witheford (2005) acknowledge the existence of what they call corporate-style management in large game development companies, which can dampen creative spirits, and lead to workers leaving to set up shop on their own. However, the newfound creative freedom can be short-lived:

'Ironically, over the period during which we conducted our interviews, two of the developers who had waxed most eloquent to us about self-management, flattened hierarchies, and creative control sold their studios to multinational publishers for millions.' (de Peuter and Dyer-Witheford, 2005)

They also acknowledge that the lawsuits are a form of resistance posed by what they call 'play slaves,' but they do not discuss the implication of the avenue chosen for this resistance. Instead, they focus on what they see as a counter-mobilisation of 'the multitude' through the subversive practices of game labour. These practices include the production of anti-capitalist games with subversive content, 'modding' ${ }^{5}$, and piracy. This is done in an attempt to re-appropriate 'the general intellect of games, re-organising it autonomously, and re-directing it toward a critique of Empire' (de Peuter and Dyer-Witheford, 2005).

However, at the same time, a large number of people working in the game production industry and other so-called knowledge industries are struggling against capitalist exploitation, using a very different approach, the framework of labour law that was developed as a result of working class struggle in the era of Fordism. This is very different approach from the kind of resistance the autonomists expect from the 'multitude'.

Clearly, more qualitative research on the experience of the creative knowledge worker and more reliable use of statistics (with clearer definitions) are needed to establish a definitive picture, but the evidence of these lawsuits suggests that it is difficult to claim that we have or are just about to move into an era of reorganised capitalism, whether this move comes as a result of new technology, capital's search for a new stable regime of accumulation or labour's continued struggle against capitalist exploitation.

It is of course easy to caricature theories of the knowledge-based economy. Many would claim that what is underway is a process that is still being negotiated through a

5 'Modding', according to Wikipedia, 'is a slang expression for the act of modifying a piece of hardware or software to perform a function not intended by someone with legal rights concerning that modification', http://en.wikipedia.org/wiki/Modding (accessed October 28, 2006). 
landscape of state regulation, new technology, right-wing ideology, and reorganisation and re-skilling of labour. It could, perhaps, be more fruitful both for our understanding of these processes and for promoting the interests of the workers in these industries to focus on this hybrid of Fordism/post-Fordism that we are currently experiencing rather than theorise about ideal typical potentialities that might be the end result. As Ned Rossiter (2003) puts it in his critique of Negri:

'There has not been a revolution [of work and production practices]. Rather, capital

has transmogrified into an informational mode of connections and relations, a

mode that does not so much come after industrial and post-industrial modes

of production as incorporate such modes within an ongoing logic of flexible

accumulation.' (Rossiter, 2003)

We need to acknowledge that capitalism today does not function quite as it did in the heyday of Fordist production practices; however there is little evidence to support the idea that it has moved into an entirely new mode of operation. Instead, new theories, or modifications of existing ones, are needed to better understand the fusion of creative work and Fordist production practices that we are currently experiencing.

(C) Leif Schumacher, 2006

\section{REFERENCES}

Aglietta, M. (1979) A theory of capitalist regulation: The US experience. London: New Left Books

Amar, A. D. (2002) Managing knowledge workers: Unleashing innovation and Productivity, Westport, CT:: Quorum Books

Bar-Cohen, L. \& D.M. Carrillo (2002) 'Labor law enforcement in California 1970-2000', The state of California labor 2002, 135-170. Retrieved April 14, 2006 from http://iir.ucla.edu/scl/ pdf02/scl2002ch6.pdf

Bass, D. (2005) 'Microsoft aims for video game heights', Seattlepi.com, March 5. Retrieved Aug. 4, 2006, from http://seattlepi.nwsource.com/business/214593_msftgames05.html

Brightman, J. (2006) 'EA settles overtime suit, Pays \$14.9 Million',

GameDailyBiz, April 26. Retrieved April 27, 2006 from_http://biz.gamedaily.com/industry/

feature/?id=12522

Campbell, C. (2006) 'America's top 20 publishing giants', NextGeneration, June 1.

Retrieved September 6, 2006 from http://www.next-gen.biz/index.php?option=com_content\& task $=$ view\&id $=3133 \&$ Itemid $=2$

Cairncross, F. (1977) The death of distance: How the communications revolution will change our lives, Boston: Harvard Business School Press

Castells, M. (2000) The rise of the network society. Volume 1: The information age: Economy society, and culture, Oxford: Blackwell Publishing

Castells, M. (2001) The Internet galaxy: Reflections on the Internet, business, and Society, New York: Oxford University Press

Cole, D. (2005) 'Interactive entertainment industry to rival size of global music Business', DFC Intelligence. Retrieved May 1, 2006 from http://www.dfcint.com/news/prnov92005.html

Coyle, D. (1998) The weightless world: Strategies for managing the digital economy, Cambridge, MA: MIT Press

de Peuter, G. \& N. Dyer-Witheford (2005) 'A playful multitude? Mobilising and counter-mobilising immaterial game labour', Fibreculture, 5. Retrieved August 3, 2006 from http://journal. fibreculture.org/issue5/depeuter_dyerwitheford.html

Dyer-Witheford, N. (2001) 'Empire, immaterial labor, the new combinations, and the global worker', Rethinking Marxism, 13(3-4): 70-80

Dyer-Witheford, N. (2002) 'Cognitive capital contested', Multitudes, October 10. Retrieved August 3, 2006 from http://multitudes.samizdat.net/Cognitive-Capital-Contested.html

Dyer-Witheford, N. (2004) 'Autonomist Marxism and the information society', Multitudes, June 3. Retrieved August 3, from http://multitudes.samizdat.net/Autonomist-Marxism-and-the.html Fahey, R. (2005) 'Videogames to lead entertainment sector boom through 2009, says PWC', GamesIndustry, October 10. Retrieved May 1, 2006 from http://www.gamesindustry.biz/content_page. 
php?aid= 12135

Feldman, C. (2005) 'EA settles labor-dispute lawsuit', Gamespot, October 5. Retrieved April 16, 2006 from http://www.gamespot.com/news/6135106.html

Feldman, C. \& T. Thorsen (2006) 'Electronic Arts cuts staff by five percent', Gamespot, February 1. Retrieved April 13, 2006 from http://www.gamespot.com/news/6143510.html

Florida, R. (2002) The rise of the creative class: And how it's transforming work, leisure, community, \& everyday life., New York: Basic Books

Florida, R. (2005) The flight of the creative class: The new global competition for talent, New York: HarperCollins Publishers Inc.

Fraser, J. A. (2001) White-collar sweatshop: The deterioration of work and its rewards in corporate America, New York: Norton

Frauenheim, E. (2004a) 'For developers, it's not all fun and games', CNET News, November 18. Retrieved April 18, 2006 from http://ecoustics-cnet.com.com/For+developers\%2C+its+not+all+fu $\mathrm{n}+$ and+games/2100-1022_3-5457274.html?tag=nl

Frauenheim, E. (2004b) 'Electronic Arts promises workplace change', CNET News, December 3. Retrieved April 18, 2006 from http://ecoustics-cnet.com.com/Electronic+Arts+promises+workplac e+change/2100-1022_3-5476714.html?tag=nl

Frauenheim, E. (2005) 'Overtime coming to Electronic Arts', CNET News, March 11. Retrieved April 16, 2006 from http://ecoustics-cnet.com.com/Overtime+coming+to+Electronic+Arts/21001022_3-5611293.html?tag=nl

Gambino, F. (1996, October) 'A critique of the Fordism of the Regulation school', Wildcat-Zirkular, 28/29. Retrieved August 6, 2006 from http://www.wildcat-www.de/en/zirkular/28/z28e_gam.htm GameDaily Staff (2006) 'Are Big Budget Console Games Sustainable?', GameDailyBiz, March 10. Retrieved March 11, 2006 from http://biz.gamedaily.com/industry/advertorial/?id=12089 Graft, K. (2006a) 'Develop names top 100 power studios', NextGeneration, April 16. Retrieved May 1, 2006 from http://www.next-gen.biz/index.php?option=com_content\&task=view\&id=2748\&Ite mid $=2$

Graft, K. (2006b) 'Game developers turn to outsourcing', NextGeneration, March 9. Retrieved March 10, 2006 from http://www.next-gen.biz/index.php?option=com_content\&task=view\&id=2447\&It emid $=2$

Handman, D. H. (2005) 'Electronic Arts settles a class action overtime lawsuit for \$15.6 million: Red flags and practical lessons for the entertainment software industry', Entertainment Law Reporter, 27(6) Retrieved April 19, 2006 from http://www.entertainmentlawreporter.com/archive/ v27n06/270601.htm

Hardt, M. \& A. Negri (2000) Empire, Cambridge, MA: Harvard University Press

Hardt, M. \& A. Negri. (2004) Multitude: War and democracy in the age of Empire, New York: Penguin Press

Harvey, D. (1989) The condition of postmodernity: An enquiry into the origins of cultural change, Cambridge, Mass: Blackwell Publishing

Heyman, T. S. (n.d.a) Electronic Arts California artists overtime litigation. Retrieved April 17, 2006 from http://www.shulaw.com/unlawful/EAovertime_new.asp

Heyman, T. S. (n.d.b) Electronic Arts California software engineers overtime litigation. Retrieved April 28, 2006 from http://www.shulaw.com/unlawful/EAovertime_California.asp

Heyman, T. S. (n.d.c) Electronic Arts Florida artists overtime litigation. Retrieved April 16, 2006 from http://www.shulaw.com/unlawful/EAovertime_Florida.asp

Holloway, J. (2002) 'Going in the wrong direction: Or, Mephistopheles - not Saint Francis of Assisi', Historical Materialism, Volume 10(1): 79-91

International Game Developers Association (2004) Quality of life white paper. Retrieved April 18, 2006 from http://www.igda.org/qol/whitepaper.php

InterNet Bankruptcy Library. (2005a) 'Electronic Arts: Plaintiffs amend employees' lawsuit in CA court', Class Action Reporter, 7(27). Retrieved April 16, 2006 from http://bankrupt. com/CAR_Public/050208.mbx

InterNet Bankruptcy Library. (2005b) 'Siebel Systems: Faces amended overtime wage lawsuit in N.D. CA., Class Action Reporter, 7(231) Retrieved April 16, 2006 from http://bankrupt. com/CAR_Public/051122.mbx

Irish, D. (2005) The game producer's handbook,. Boston: Thomson Course Technology PTR Jessop, B. (2002) The future of the capitalist state, Cambridge, UK: Polity Press Jordan, H. \& M. Steen (2000) 'New law exempts some from overtime applies to high-tech professionals making \$41 or more an hour', San Jose Mercury News, September 20:C1 Kline, S., N. Dyer-Witheford, and G. de Peuter (2003) Digital play: The interaction of technology, culture, and marketing, Montreal \& Kingston: McGill-Queen's University Press Leadbeater, C. (1997) 'A slice of the Silicon pie', New Statesman, 126(4335)

Liepitz, A. (1987) Mirages and miracles: The crisis in global Fordism, London: Verso Lombardi, R. (2006) 'Oppressed gaming workers liberated by IT best practices', Globe and Mail, April 12. Retrieved April 15, 2006 from http://www.theglobeandmail.com/servlet/story/ RTGAM.20060412.gtgameapr12/BNStory/Technology/AtPlay Loughrey, P. (2006) 'Probst performing well as EA CEO', GamesIndustry, April 24. Retrieved 
May 1, 2006 from http://www.gamesindustry.biz/content_page.php?aid=16301

Marsh, M. C. (2000) New California law creates overtime exemptions for some computer personnel. Retrieved April 14, 2006 from http://www.yourlegalcorner.com/employment/ oct2000.html

Mieszkowski, K. (2004) Santa's sweatshop, Salon.com, December 2

Muller, T. (2005) EA settles class action on overtime, October 5. Retrieved April 17, 2006, from http://www.info.ea.com/news/pr/pr691.pdf

Muller, T. (2006) EA settles engineer class action on overtime, April 26. http://www.info. ea.com/news/pr/pr767.pdf

Negri, A. (2003) 'Public sphere, labour and multitude', MakeWorlds, 3. Retrieved April 17 2006 from http://makeworlds.org/node/11

Pham, A. (2004) 'Working too hard in an industry of fun and games', Los Angeles Times,

November 17:C1

Reich, R. B. (1991) The work of nations: Preparing ourselves for $21^{\text {st }}$ century capitalism, New York, NY: Knopff Publishing

Reich, R. B. (2002) The future of success: Working and living in the new economy, Toronto:

Random House

Richtel, M. (2005) 'Fringes vs. basics in Silicon Valley', New York Times, March 9:C1

Robinson, E. (2005) Why crunch mode doesn't work: six lessons. Retrieved April 25, 2006 from http://www.igda.org/articles/erobinson_crunch.php

Rossiter, N. (2003, December) 'Report: Creative labour and the role of intellectual Property', Fibreculture, 1. Retrieved August 3, 2006 from http://journal.fibreculture.org/issue1/issue 1_rossiter.html

Schubert, R. C., J.J. Reed, M. P.Kolbe, T. V.Urmy, \& T.S. Heyman (2004) First amended class action and representative action complaint. Retrieved April 13, 2006 from http://www.eaovertimecase.com/First\%20Amended\%20Complaint.pdf

Schubert, R. C., J.J. Reed, M. P.Kolbe, T. V.Urmy, \& T.S. Heyman. (2005) Class action and representative action complaint. Retrieved April 13, 2006 from http://www.schubert-reed. com/Sony\%20Complaint.pdf

Shepherd, C. and K.Graft (2006a) 'GMC: Hardware guys to blame', NextGeneration, March 8. Retrieved March 9, 2006 from http://www.next-gen.biz/index.php?option=com_content\&tas $\mathrm{k}=$ view\&id $=2440 \&$ Itemid $=2$

Shepherd, C. and K. Graft (2006b) 'GMC: Innovation is Key Challenge', NextGeneration, March 8. Retrieved March 9, from http://www.next-gen.biz/index.php?option=com_content\&task=vi ew\&id=2438\&Itemid $=2$

Smith, D. (2004) 'EA Faces Class-Action Overtime Suit', 1UP.com, November 12. Retrieved, April 15, 2006 from http://cgw.1up.com/do/newsStory?cId=3136538

Smith, R. W., T.V. Urmy, \& T.S.Heyman (2005) First amended class and collective action complaint.

Retrieved April 16, 2006 from http://www.shulaw.com/documents/complaints/EA\%20Florida\%20

First $\% 20$ Amended\%20Class\%20and\%20Collective\%20Action\%20Complaint.pdf

State of California (2003) Exemptions from the overtime laws - Glossary. Retrieved, April 13, 2006 from http://www.dir.ca.gov/dlse/Glossary.asp?Button 1=E\#employee\%20in\%20the\%20computer $\% 20$ software\%20field

Stross, R. (2004) 'When a video game stops being fun', New York Times, November 21. Re-

trieved April 14, 2006 from http://www.nytimes.com/2004/11/21/business/yourmoney/21digi. html?ex=1258693200\&en=40a60cc6d7971ab2\&ei=5090\&partner=rssuserland

Takahashi, D. (2005) 'Nicole Wong's story on Electronic Arts overtime lawsuit settlement', Mercury News, October 7. Retrieved April 16, 2006 from http://blogs.mercurynews.com/aei/2005/10/ guest_posts_nic.html

Thoburn, N. (2001) 'Autonomous production? On Negri's “new synthesis”, Theory, Culture \& Society, 18(5):75-96

Urmy, T. V. and T.S.Heyman (2006) Activision overtime litigation. Retrieved April 29, 2006 from http://www.shulaw.com/unlawful/Activision.asp

Wells, J. (2006) 'A city worthy of Buzz', The Toronto Star, March 11:L1. 